\title{
Environmental limits for survival of sarcoma cells from the soft-shell clam Mya arenaria
}

\author{
Inke Sunila ${ }^{1 *}$, C. Austin Farley ${ }^{2}$ \\ ${ }^{1}$ University of Helsinki, Department of Zoology, Arkadiankatu 7, SF-00100 Helsinki, Finland \\ ${ }^{2}$ National Marine Fisheries Service, Oxiord Laboratory, Oxford, Maryland 21654, USA
}

\begin{abstract}
Survival of sarcoma cells from the soft-shell clam Mya arenaria was studied in vitro. Hemolymph was withdrawn from clams with advanced stages of sarcoma and placed in seawater in 'Farley chambers'. Sarcoma cells were exposed for $6 \mathrm{~h}$ to different salinities, temperatures, $\mathrm{pH}$, and copper concentrations. Cell viability was determined using a new trypan blue-safranin stain on permanent monolayer slides. Counts of live and dead cells were made to determine percent mortality. The lethal low salinity was $0.5 \%$; $\mathrm{TL}_{50}$ (tolerance limit, $50 \%$ mortality) was $1.7 \%$ and the lethal high salinity was $>35 \%$. Lethal high temperature was $40^{\circ} \mathrm{C}$ and $\mathrm{TL}_{50}$ was $33.7^{\circ} \mathrm{C}$. Of cells frozen at $-20^{\circ} \mathrm{C}$ for $6 \mathrm{~h}, 31 \%$ were viable. The lethal low pH was 3.6 , but no mortality occurred at pH 4.0 to 9.3. TL 50 was $\mathrm{pH}$ 3.9. LC $\mathrm{L}_{50}$ for copper was $1.9 \mathrm{mg} \mathrm{l}^{-1}$ Sarcoma cells had broad tolerance to changes in the environmental factors tested. It is concluded that sarcoma cells can survive variations in ambient environmental factors long enough to be transferred from sick clams to healthy ones, permitting transplantation of the disease under natural conditions.
\end{abstract}

\section{INTRODUCTION}

Epizootic sarcoma in soft-shell clams Mya arenaria from Chesapeake Bay, USA, was reported by Farley et al. (1986). Rare first cases were seen in 1979 with epizootic prevalence developing in winter 1983. Prevalences of up to $65 \%$ were seen the next year, peaking at $91 \%$ in 1985 (Farley 1989). In earlier studies, this disease in soft-shell clams was called hematopoietic neoplasia on the unproven assumption that the cell origin was hemocytes (Farley et al. 1986, Farley 1989). This type of neoplasm previously had been found in clams from numerous sites in New England, USA (Barry \& Yevich 1975, Yevich \& Barszcz 1976, Brown et al. 1977, Cooper et al. 1982, Reinisch et al. 1984, Brousseau 1987).

Neoplastic cells have large hyperchromatic nuclei, usually with one nucleolus. Mitosis is common and abnormal mitotic figures have been found (Farley et al. 1986). Sarcoma cell proliferation results in increasing percentages of neoplastic cells in the hemolymph, eventually resulting in the death of the clam (Cooper et al. 1982, Farley 1989, Farley et al. 1989).

\footnotetext{
- Present address: National Marine Fisheries Service, Oxford Laboratory, Oxford, Maryland 21654, USA
}

The possible causes of this disease were reviewed recently (Farley et al. 1989); a viral origin as well as point-source chemical oncogen activation or pollution have been suggested. Farley (1989) demonstrated the transplantability of the disease. Sarcoma cells from clams in advanced stages of the disease were injected into healthy clams via the musculature of the siphon. Injected clams were diagnosed positive within $1 \frac{1}{2} \mathrm{mo}$.

The epizootiological features of this disease in Chesapeake Bay clam populations suggest that it is an infectious process. If sarcoma cells are able to survive in seawater, they could infect healthy clams after being released by dying clams, either by cell transplantation or by transmission of a virus. In this work, we studied experimentally the effect of environmental parameters on the survival of sarcoma cells in seawater by varying salinity, temperature, $\mathrm{pH}$, and concentration of copper in efforts to explain epizootic differences observed in natural populations.

\section{MATERIALS AND METHODS}

Sarcomatous soft-shell clams were collected in July 1988 from Swan Point (northern Chesapeake Bay). Seawater temperature was $26^{\circ} \mathrm{C}$, surface salinity was 
$10 \%$, and depth was 2 to $3 \mathrm{~m}$. Clams were held in circulating seawater at the National Marine Fisheries Service Laboratory in Oxford, Maryland $\left(\mathrm{T}=24{ }^{\circ} \mathrm{C}, \mathrm{S}=\right.$ $15 \%$ ) for $2 \mathrm{~d}$ to 2 mo prior to experimental use. Clams were diagnosed for sarcoma by histocytology (Farley et al. 1986). Sarcoma stages were determined on the basis of the ratio between normal hemocytes and sarcoma cells; Stage 1 was 1 to 9 cells per 100000 ; Stage 2 was 1 to 9 sarcoma cells per 10000 ; Stage 3 was 1 to 9 sarcoma cells per 1000 ; Stage 4 was 1 to $9 \%$ sarcoma cells; Stage 5 was 10 to $49 \%$ sarcoma cells; Stage 6 was 50 to $89 \%$ sarcoma cells; and Stage 7 was 90 to $100 \%$ sarcoma cells (Farley et al. 1989). Two $\mathrm{ml}$ of sterile water, adjusted to particular salinities by addition of artificial sea salt, was placed in $24 \times 24 \times 9 \mathrm{~mm}$ 'Farley chambers' (Reinisch et al. 1983) on polylysine-coated microscope slides. One drop of undiluted hemolymph (Stage 7) was placed in each chamber and covered with a glass lid.

The life span of sarcoma cells was followed for $48 \mathrm{~h}$ during the first experiment $\left(\mathrm{T}=24^{\circ} \mathrm{C}, \mathrm{S}=15 \%\right.$ ); after that an exposure time of $6 \mathrm{~h}$ was used. After the exposures, one drop of trypan blue was placed in each chamber, and the slides were allowed to dry.

Cells were stained by a modification of the trypan blue vital staining technique for detecting dead and living cells on permanent monolayer preparations. The procedure was as follows.

Trypan blue-safranin stain. Formula: trypan blue solution, $0.1 \%$ aqueous, safranin, $0.3 \%$ aqueous. (1) Trypan blue -1 drop in $2 \mathrm{ml}$ of seawater in the 'Farley' chamber' - 15 min. (2) Remove liquid and allow the preparation to air-dry. (3) Fix in $1 \mathrm{G} 4 \mathrm{~F}$ modified McDowell fixative (Farley et al. 1986) - 5 min. (4) Running tap water - 2 min. (5) Safranin - 2 min. (6) $1: 9$ ethanol/butanol - 1 dip. (7) Butanol - 2 min. (8) Butanol - 5 min. (9) Xylene - 5 min. (10) Xylene - 5 min. (11) Mount in synthetic mounting medium. Result: live cells stain red, dead cells stain blue.

Duplicate preparations were made in each test. Proportions of living versus dead cells were determined by counting an average of 200 cells from each test concentration

Salinity experiment. Water was prepared with artifjcial sea salt to salinities $0,0.25,0.5,1,2.5,5,7.5,10,20$, 25,30 , and $35 \%$. Exposure temperature was $25^{\circ} \mathrm{C}$. Sarcoma cells from 1 clam were used for all chambers.

Temperature experiments. Covered 'Farley chambers' were placed in boxes containing water-saturated paper towels to retard evaporation at high temperatures. Temperatures of $0,4,13,20,27,37$, and $40^{\circ} \mathrm{C}$ were tested in the first experiment. Temperatures of $27,29,31,33,37$ and $39^{\circ} \mathrm{C}$ were tested in the second experiment.

Sarcoma cells from 1 individual clam were used for each test. The survival of sarcoma cells in $-20^{\circ} \mathrm{C}$ frozen seawater was tested using hemolymph from 15 diseased clams. Three chambers were made from the hemolymph of each clam and the cells were allowed to settle for $1 / 2 \mathrm{~h}$ before freezing. Chambers from 5 clams served as controls and were kept at $25^{\circ} \mathrm{C}$ during the experiment. After $6 \mathrm{~h}$ at $-20^{\circ} \mathrm{C}$, samples were thawed at room temperature. One slide from each clam was stained with trypan blue-safranin, and a duplicate slide was stained for 30 min with the supravital stain Janus green to detect mitochondria (Lillie 1965). A third slide was stained with nitroblue tetrazolium to detect mitochondrial succinate dehydrogenase activity (Pearse 1968). Salinity was $15 \%$ for temperature experiments.

$\mathrm{pH}$ experiments. The $\mathrm{pH}$ of $15 \%$ seawater was adjusted using $0.1 \mathrm{~N} \mathrm{H}_{2} \mathrm{SO}_{4}$ and $\mathrm{NaOH}$ to $3.6,3.8,4.0$, $5.0,6.0,7.0,8.0,9.0$, and 9.3. Exposure temperature was at $25^{\circ} \mathrm{C}$. Water in the chambers was replaced by seawater of $\mathrm{pH} 8$, prior to adding trypan blue, to prevent precipitation of the stain.

Copper experiments. Copper concentrations $0,0.05$, $0.1,0.25,0.5,0.75,1.0,2.5,5.0,7.5$, and $10 \mathrm{mg} \mathrm{l}^{-1}$ $\left(\mathrm{CuCl}_{2} \cdot 2 \mathrm{H}_{2} \mathrm{O}\right)$ were tested in $15 \%$ seawater at $25^{\circ} \mathrm{C}$.

\section{RESULTS}

Sarcoma cells survived the $48 \mathrm{~h}$ experiment in seawater. In exposure experiments, sarcoma cells showed wide tolerances to changes in salinity, temperature, and $\mathrm{pH}$ but were sensitive to dissolved $\mathrm{Cu}^{+2}$ cations.

\section{Salinity experiments}

Percentages of dead sarcoma cells in different salinities are presented in Fig. 1. The lethal low salinity was $0.5 \%$ ( $100 \%$ mortality). The $\mathrm{TL}_{50}$ (tolerance limit,

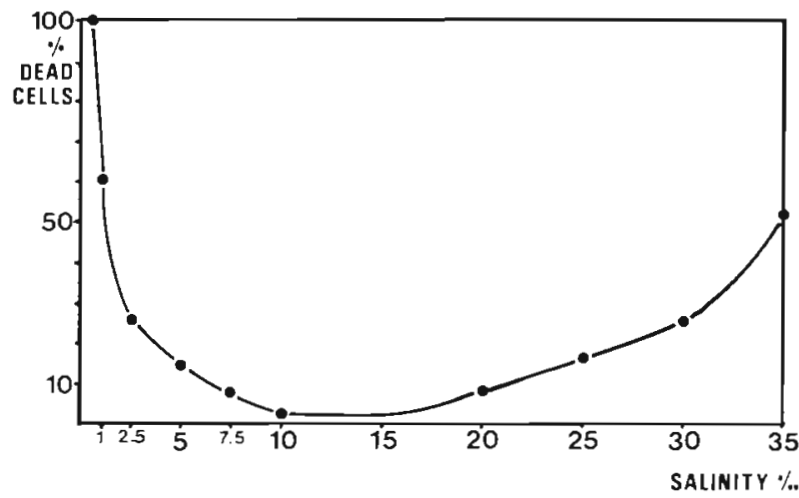

Fig. 1. Mya arenaria. Survival of sarcoma cells from the softshell clam after 6 h exposure to different salinities $\left(25^{\circ} \mathrm{C}\right)$ Percentage of dead sarcoma cells plotted against salinity 
$50 \%$ mortality) for low salinity was $1.73 \%$ (95\% confidence limits: lower 1.44, upper 2.07 probit analysis). Salinities higher than $35 \%$ could not be tested because of precipitation of the trypan blue stain. The $\mathrm{TL}_{50}$ for high salinity was $35.85 \%$ (extrapolated value, 95\% confidence limits: lower 33.56, upper 39.84).

\section{Temperature experiments}

Percentages of dead cells in the temperature range from 0 to $40^{\circ} \mathrm{C}$ are presented in Fig. 2. Lowest mortality occurred in the 20 and $27^{\circ} \mathrm{C}$ exposures, values closest to the temperature of aquarium water $\left(24^{\circ} \mathrm{C}\right)$. The lethal high temperature was $40^{\circ} \mathrm{C}(100 \%$ mortality $)$. $\mathrm{TL}_{50}$ was $33.05^{\circ} \mathrm{C}(95 \%$ confidence limits: lower 32.18 , upper 33.98).

The average survival of frozen cells was $31 \%$. Results obtained from trypan blue-safranin or Janus green were not significantly different (Student's t-test, $p>0.05$; Table 1). Live cells gave a positive nitroblue tetrazolium reaction.

\section{pH experiments}

At $\mathrm{pH} 4.00$, no mortality above control level occurred, but all cells were dead at pH 3.60 (Fig. 3). The $\mathrm{TL}_{50}$ was 3.89 (95\% confidence limits: lower 3.87, upper 3.91).

\section{Copper experiments}

Fig. 4 shows survival of sarcoma cells in different concentrations of copper. The lethal concentration ( $100 \%$ mortality) was $7.50 \mathrm{mg} \mathrm{l}^{-1}$, while the $\mathrm{LC}_{50}$ was $1.86 \mathrm{mg} \mathrm{l}^{-1}$ (95\% confidence limits: lower 1.63, upper 2.10)

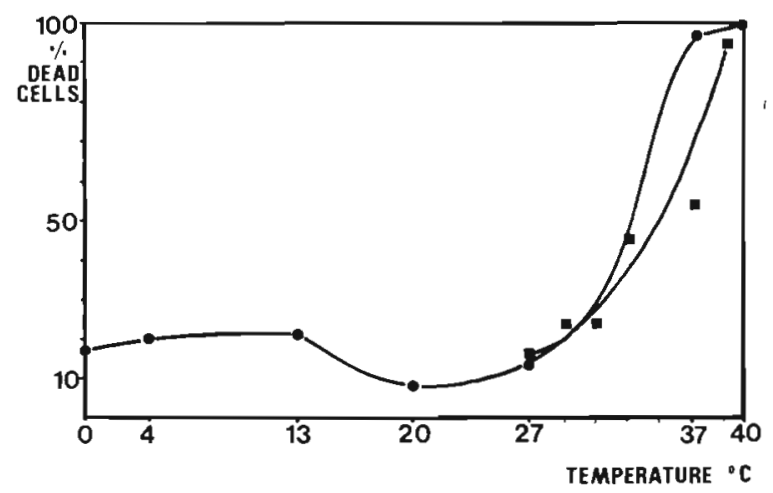

Fig. 2. Mya arenaria. Survival of sarcoma cells from the softshell clam after $6 \mathrm{~h}$ exposure to temperatures from 0 to $40^{\circ} \mathrm{C}$ (•) and from 27 to $39^{\circ} \mathrm{C}$ (⿴) ( $\mathrm{S}=15 \%$ ). Percentage of dead sarcoma cells plotted against temperature
Table 1. Percentages of live sarcoma cells from the soft-shell clam Mya arenaria after freezing at $-20^{\circ} \mathrm{C}$ for $6 \mathrm{~h}(\mathrm{~S}=15 \%)$. Viability of cells was determined by trypan blue-safranin stain on permanent slides and vital stain Janus green (significance of stain determination of viability was evaluated using the t-test)

\begin{tabular}{|cccc|}
\hline \multicolumn{2}{c}{ Clam no. } & Trypan blue & Janus green \\
\hline \multirow{2}{*}{ Control } & 1 & 100.0 & 100.0 \\
& 2 & 97.0 & 95.2 \\
& 3 & - & 98.1 \\
& 4 & 97.7 & 97.1 \\
Frozen & 5 & 99.0 & 100.0 \\
& 6 & 17.8 & 15.5 \\
& 7 & 19.3 & - \\
& 8 & 23.9 & 25.5 \\
& 9 & 45.7 & 25.0 \\
& 10 & 28.6 & 58.6 \\
& 11 & 52.7 & 40.8 \\
& 12 & 19.8 & 35.3 \\
Mean & 13 & 12.0 & 47.7 \\
SD & 14 & 16.5 & 26.3 \\
t $=1.636$ & & 24.8 & 54.8 \\
& 15 & 26.1 & 36.6 \\
& & 13.125 & 14.861 \\
\hline
\end{tabular}

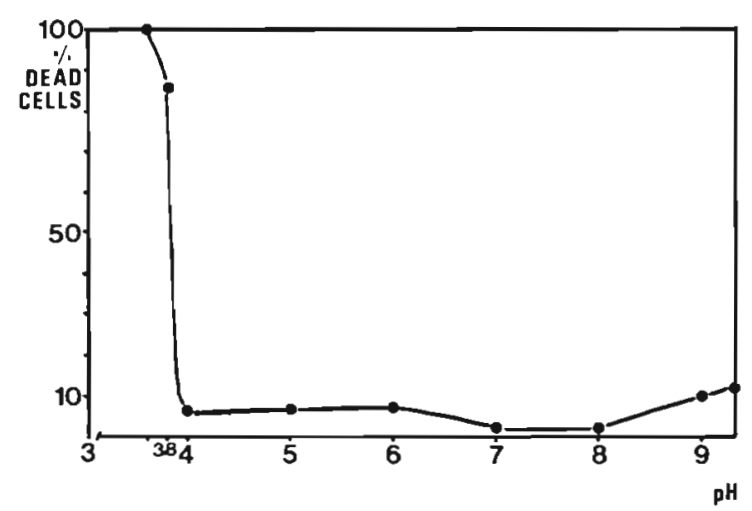

Fig. 3. Mya arenaria. Survival of sarcoma cells from the softshell clam after $6 \mathrm{~h}$ exposure to different $\mathrm{pH}$ values $\left(25^{\circ} \mathrm{C}, \mathrm{S}=\right.$ $15 \%$. Percentage of dead sarcoma cells plotted against $\mathrm{pH}$

\section{DISCUSSION}

Sarcoma cells survived at least for $48 \mathrm{~h}$ in seawater in chambers. The number of bacteria and ciliates increased, however, under these static circumstances; therefore, a 6 h exposure time was used because contamination was minimal and no mortality greater than $10 \%$ occurred in control groups.

Viability of sarcoma cells was determined via the trypan blue method. Live cells exclude the stain while dead or damaged cells that have lost membrane integrity take it up (Hoskins et al. 1956). Living cells were 


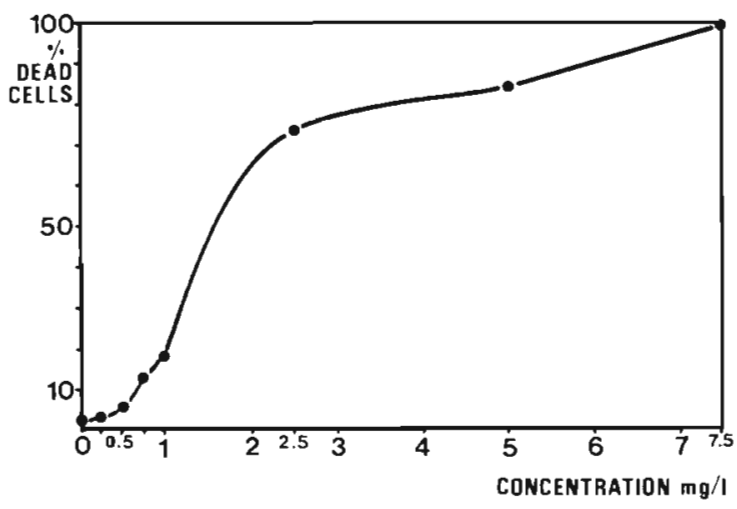

Fig. 4. Mya arenaria. Survival of sarcoma cells from the softshell clam after $6 \mathrm{~h}$ exposure to different concentrations of copper $\left(25^{\circ} \mathrm{C}, \mathrm{S}=15 \%\right)$. Percentage of dead sarcoma cells pioiied againsi cuncentudiun

stained only with the safranin, which was used as a counterstain in order to see nuclear features needed to identify the type of cell.

This study demonstrated that clam sarcoma cells were extremely tolerant to a wide range of salinity and were more sensitive to low salinities than to high salinities. The lowest mortality occurred in salinities of 10 and $20 \%$, the conditions most similar to the salinity of the sampling stations where sarcomatous populations are found in the field (Farley et al. 1989).

The extremes of the temperature range tolerated by sarcoma cells from $-20^{\circ} \mathrm{C}$ to $37^{\circ} \mathrm{C}$ (Table 1 ; Fig. 2) were beyond any condition they normally would encounter, i.e., the freezing point of estuarine water $\left(-2^{\circ} \mathrm{C}\right)$ and up to $30^{\circ} \mathrm{C}$. Sarcoma cells survived a $\mathrm{pH}$ range from 4.0 to 9.3. Upper Chesapeake Bay $\mathrm{pH}$ ranges are rarely below 6.5 or above 8.5 (EPA 1983). Tolerance to low $\mathrm{pH}$ is typical for malignant neoplastic cells; Ehrlich ascites carcinoma cells from mice withstood variations in $\mathrm{pH}$ from 3.68 to 9.71 (Collier 1934).

While sarcoma cells were relatively sensitive to copper $\left(\mathrm{LC}_{50}, 1.86 \mathrm{mg} \mathrm{l}^{-1}\right)$, concentrations of this mag. nitude do not occur in natural waters. Copper concentrations in seawater in the sampling area range from 0.37 to $1.64 \mathrm{\mu g} \mathrm{l}^{-1}$ (EPA 1983)

Results inherent in the test model suggest at least a $6 \mathrm{~h}$ period in which sarcoma cells may infect another clam by drifting in seawater after release from an affected clam. Clearly they can stay alive in seawater long enough to transmit the disease either by cell transplantation or by transmission of an infectious agent such as a virus, even one that was fastidious in regard to the necessity of cell association. Sarcoma cells had a broad tolerance of environmental factors, i.e. in salinity, temperature, or $\mathrm{pH}$, and survived under conditions that the clams themselves cannot survive.
A review of locations of sarcomatous and sarcomafree populations of soft-shell clams in Chesapeake Bay reported by Farley et al. (1989) suggests that sarcomafree populations tend to occur primarily at sites in the upper reaches of estuaries. According to EPA (1983), these sites are located closer to sources of low salinity, lower $\mathrm{pH}$, and pollution. According to our preliminary tests, concurrent exposure to the environmental factors studied in this paper could possibly explain several locations where the disease does not exist, i.e. lower salinities and pHs at 'upstream' sites such as Piney Point and Race Track (Farley et al. 1989).

Further studies on specific field conditions and concomitant occurrence of these physical parameters may help to clarify these remaining questions.

Acknowledgements. The senior author was supported by the Research Council for Environmental Science, Academy of Finland. Research space and materials were provided by the Oxford Cooperative Laboratory, U.S. Department of Commerce/Maryland Department of Natural Resources, Oxford, Maryland, USA. We thank Ms Jane Swann for secretarial services and technical editing.

\section{LITERATURE CITED}

Barry, M., Yevich, P. P. (1975). The ecological, chemical and histopathological evaluation of an oil spill site. II. Histopathological studies. Mar. Pollut. Bull. 6: 171-1.73

Brousseau, D. J. (1987). Seasonal aspects of sarcomatous neoplasia in Mya arenaria (soft-shell clam) from Long Island Sound. J. Invertebr Pathol. 50: 269-276

Brown, R. S., Wolke, R. E., Saila, S. B., Brown, C. W. (1977). Prevalence of neoplasia in 10 New England populations of the soft-shelled clam (Mya arenaria). Ann. N.Y Acad. Sci. 298: 522-534

Collier, W. A. (1934). Uber die Natur des Ehrlichschen. Mäusecarcinoms. Die Bedeutung der Wasserstoffionenkonzentration. Z. Krebsforsch. 40: 586-590

Cooper, K. R., Brown, R. S., Chang, P. W. (1982). The course and mortality of a hematopoietic neoplasm in the soft-shell clam, Mya arenaria. J. Invertebr. Pathol. 39: 149-157

EPA (1983). Chesapeake Bay: a profile of environmental change. U.S. Environmental Protection Agency, Philadelphia, Pennsylvania

Farley, C. A. (1.989). Selected aspects of neoplastic progression in mollusks. In: Kaiser, H. E. (ed.) Cancer growth and progression, Vol. 5, Comparative aspects of tumor development. Kluwer Academic PubI., Dordrecht, Boston, London, p. 29-31

Farley, C. A., Otto, S. V., Reinisch, C. L. (1986). New occurrence of epizootic sarcoma in Chesapeake Bay soft shell clams (Mya arenaria). Fish. Bull. U.S. 84: 852-857

Farley, C. A., Plutschak, D. L., Scott, R. F. (1989). Epizootiology and range of transmissible sarcoma in Maryland softshelled clams 1984-1988. J. Environ. Health Persp. (in press)

Hoskins. J. M., Meynell, G. G., Sanders, F. K. (1956). A compinison of methods for estimating the viable count of a suspension of tumour cells. Exp. Cell Res. 11 297-305

Lillie, R. D. (1965). Histopathologic technic and practical histochemistry. McGiraw-Hill, New York 
Pearse, A. G. E. (1968). Histochemistry. Theoretical and applied. Little, Brown and Co., Boston

Reinisch, C. L., Charles, A. M., Troutner, J. (1983). Unique antigens on neoplastic cells of the soft shell clam $M V d$ arenaria. Dev. Comp. Immunol. 7. 33-39

Responsible Subject Editor Dr A. K. Sparks, Seattle, Washington, USA
Reinisch, C. L., Charles, A. M., Stone, A. M. (1984). Epizootic neoplasia in soft shell clams collected from New Bedford harbor Haz. Waste 1: 73-81

Yevich, P. P., Barszcz, C. A. (1976). Gonadal and hematopoietic neoplasms in Mya arenaria. Mar Fish. Rev., 38: 42-43

Manuscript first received: April 6, 1989

Revised version accepted: July 18, 1989 